\title{
Editorial
}

Dermatology

\section{The Concept of 'Smokers' Boils' Is Suggestive of a New Hypothesis on the Pathogenesis of Hidradenitis Suppurativa}

\author{
Gregor B.E. Jemec \\ Department of Dermatology, Roskilde Hospital, Health Sciences Faculty, University of Copenhagen, \\ Roskilde, Denmark
}

Clinical science evolves at the interface between a disease and an observant physician with the gift for identifying patterns or constellations of signs and symptoms. Once a coherent hypothesis has been presented on the basis of logical deductive reasoning, additional structured experimental studies are necessary to substantiate or reject it, always bearing in mind that the physical and biological complexity of our world inevitably relegates absolute proof to more absolute sciences such as mathematics, philosophy or theology. The paper by Happle and König [1] provides a welcome, testable new hypothesis for dermatologists to pursue within the recently proposed framework of metabolizing acquired dioxin-induced skin hamartomas.

The renaming of hidradenitis suppurativa (HS) to 'smokers' boils', as proposed by Happle and König [1], provides a welcome opportunity to hypothesise about the pathogenesis of this most distressing disease. The authors correctly point out that there is a marked preponderance of tobacco smokers among HS patients, and active tobacco smoking appears to be associated with more severe disease; of note, the hitherto most famous HS patient in history, Karl Marx, was a heavy smoker [2-9]. Similarly, HS patients have been shown to have a higher incidence of cancers, suggesting exposure to a carcinogen [10]. The

\section{KARGER}

Fax +4161306 1234

E-Mail karger@karger.ch

www.karger.com (c) 2011 S. Karger AG, Basel

$1018-8665 / 11 / 2223-0196 \$ 38.00 / 0$

Accessible online at: www.karger.com/drm experimental investigation of how tobacco cessation affects HS has not as yet been carried out, although it would provide convincing empirical evidence in favour of a causal association in agreement with Koch's postulates regarding infectious diseases. On the other hand, lung cancer is not overrepresented in HS cases, not all patients smoke - even though a majority does - and, finally, particularly heavy tobacco smoking has also been associated with fewer rather than more inflammatory lesions in acne patients [11].

It would therefore be helpful to supplement this interesting clinical-epidemiological hypothesis with some pathophysiological considerations. Several hypotheses have been proposed concerning HS, none of which readily accommodate a role for smoking [12]. A recent observation, however, has suggested a possible pathogenic link between tobacco and HS via the sebaceous gland.

Previous histological studies have identified the pilosebaceous unit as the centre of HS [13-16], but no description is offered of the possible role of the sebaceous gland. Recently, sebaceous glands were shown to be reduced in number as well as in size in clinically uninvolved follicles of HS patients, suggesting a possible pathogenic role [17]. This is in good agreement with the reduced sebum excretion previously described [18]. 
Squamous metaplasia and shrinkage of the sebaceous glands also occur in chloracne $[19,20]$. Furthermore, it is possible to identify additional clinical similarities between HS and chloracne: atypical acneiform lesions in inverse areas, the late onset, sterile abscesses and, in some cases, the apparent absence of measurable exposure to halogenated compounds [20-22].

The population is exposed to steady low levels of halogenated compounds from the environment and addition- ally from smoking tobacco $[23,24]$. It may therefore be speculated that HS is related to chloracne, and that additional tobacco smoking causes this to manifest itself in predisposed individuals in similar mechanisms, either due to the magnitude of exposure or increased individual susceptibility. The clinicopathological constellation of absent/reduced sebaceous glands associated with cysts has recently been recognised as 'metabolizing acquired dioxin-induced skin hamartomas' [25].

\section{References}

1 Happle R, König A: Smokers' boils. Dermatology DOI: $10.1159 / 000327923$.

2 Breitkopf C, Bockhorst J, Lippold A, Ernst K, Hundeiker M: Pyodermia fistulans sinifica (Acne inversa) und Rauchgewohnheiten. Z Hautkr 1995;70:332-334.

3 König A, Lehmann C, Rompel R, Happle $\mathrm{R}$ : Cigarette smoking as a triggering factor of hidradenitis suppurativa. Dermatology 1999;198:261-264.

4 Jemec GBE, Revuz J, Leyden JJ: Hidradenitis Suppurativa. Berlin, Springer, 2006.

5 Sartorius K, Emtestam L, Jemec GB, Lapins $\mathrm{J}$ : Objective scoring of hidradenitis suppurativa reflecting the role of tobacco smoking and obesity. Br J Dermatol 2009;161:831-839.

-6 Sartorius K, Killasli H, Heilborn J, Jemec GB, Lapins J, Emtestam L: Interobserver variability of clinical scores in hidradenitis suppurativa is low. Br J Dermatol 2010;162:12611268.

7 Shuster S: A lesson to be learned from Karl Marx: smoking triggers hidradenitis suppurativa (author reply). Br J Dermatol 2008;159: 256-257.

8 Jemec GB: The revolutionary consequences of skin disease. Br J Dermatol 2008;158: 1382-1383.

9 http://www.notablebiographies.com/Ma$\mathrm{Mo} / \mathrm{Marx}-\mathrm{Karl} . \mathrm{html}$.

10 Lapins J, Ye W, Nyrén O, Emtestam L: Incidence of cancer among patients with hidradenitis suppurativa. Arch Dermatol 2001;137: $730-734$.
11 Klaz I, Kochba I, Shohat T, Zarka S, Brenner $S$ : Severe acne vulgaris and tobacco smoking in young men. J Invest Dermatol 2006;126: 1749-1752.

12 Kurzen H, Kurokawa I, Jemec GB, Emtestam L, Sellheyer K, Giamarellos-Bourboulis EJ, Nagy I, Bechara FG, Sartorius K, Lapins J, Krahl D, Altmeyer P, Revuz J, Zouboulis CC: What causes hidradenitis suppurativa? Exp Dermatol 2008; 17:455-456, discussion 457472.

13 Yu CC, Cook MG: Hidradenitis suppurativa: a disease of follicular epithelium, rather than apocrine glands. Br J Dermatol 1990;122: 763-769.

14 Jemec GB, Hansen U: Histology of hidradenitis suppurativa. J Am Acad Dermatol 1996; 34:994-999.

15 Jemec GB, Thomsen BM, Hansen U: The homogeneity of hidradenitis suppurativa lesions: a histological study of intra-individual variation. APMIS 1997;105:378-383.

16 von Laffert $M$, Helmbold P, Wohlrab J, Fiedler E, Stadie V, Marsch WC: Hidradenitis suppurativa (acne inversa): early inflammatory events at terminal follicles and at interfollicular epidermis. Exp Dermatol 2010; 19:533-537.

17 Kamp S, Fiehn AM, Stenderup K, Rosada C, Pakkenberg B, Kemp K, Dam TN, Jemec GB: Hidradenitis suppurativa: a disease of the absent sebaceous gland? Sebaceous gland number and volume are significantly reduced in uninvolved hair follicles from patients with hidradenitis suppurativa. Br J Dermatol 2011;164:1017-1022.
18 Jemec GB, Gniadecka M: Sebum excretion in hidradenitis suppurativa. Dermatology 1997; 194:325-328.

19 Panteleyev AA, Bickers DR: Dioxin-induced chloracne: reconstructing the cellular and molecular mechanisms of a classic environmental disease. Exp Dermatol 2006;15:705730 .

$20 \mathrm{Ju}$ Q, Fimmel S, Hinz N, Stahlmann R, Xia L, Zouboulis CC: 2,3,7,8-Tetrachlorodibenzo$p$-dioxin alters sebaceous gland cell differentiation in vitro. Exp Dermatol 2011;20:320325.

21 Passarini B, Infusino SD, Kasapi E: Chloracne: still cause for concern. Dermatology 2010;221:63-70.

22 Poli F, Wolkenstein P, Revuz J: Back and face involvement in hidradenitis suppurativa. Dermatology 2010;221:137-141.

23 Gies A, Neumeier G, Rappolder M, Konietzka R: Risk assessment of dioxins and dioxinlike PCBs in food: comments by the German Federal Environmental Agency. Chemosphere 2007;67:S344-S349.

24 Wilson CL, Bodnar JA, Brown BG, Morgan WT, Potts RJ, Borgerding MF: Assessment of dioxin and dioxin-like compounds in mainstream smoke from selected US cigarette brands and reference cigarettes. Food Chem Toxicol 2008;46:1721-1733.

25 Saurat JH, Sorg O: Chloracne, a misnomer and its implications. Dermatology 2010;221: 23-26. 